\title{
Footsteps of the European Society for Muscle Research (1971-2008)
}

Schaub, Marcus C

DOI: https://doi.org/10.1007/s10974-008-9163-8

Posted at the Zurich Open Repository and Archive, University of Zurich ZORA URL: https://doi.org/10.5167/uzh-156585

Journal Article

Published Version

Originally published at:

Schaub, Marcus C (2008). Footsteps of the European Society for Muscle Research (1971-2008). Journal of muscle research and cell motility, 29(6-8):151-154.

DOI: https://doi.org/10.1007/s10974-008-9163-8 


\title{
Footsteps of the European society for muscle research (1971-2008)
}

\author{
Marcus C. Schaub
}

Received: 21 November 2008 / Accepted: 19 December 2008/Published online: 20 January 2009

(C) Springer Science+Business Media B.V. 2009

Back from the splendid XXXVIIth European Muscle Conference (EMC) 2008 held in Oxford at the beautiful Keble College (organised by Steven Marston and Charles Redwood), it may be appropriate to look back for a moment to the beginnings of this annual institution. This implies that before 2008 there were held another 36 Muscle Meetings (Table 1), and this reaches well back into the precomputer era, an era where the history meets the misty dawn of the EMC. Originally, EMC meant "European Muscle Club" which was born in 1971. Misty it is because the records may be laden with gaps here and there as in the pre-computer era not everything was filed away in black and white on paper. At this year's meeting in Oxford, as often at earlier meetings as well, a fair amount of young scientists, new to the scene, have appeared, and this makes these meetings so charming and interesting.

Returning back to Zurich in 1970 from a three and half years postdoc with Sam V. Perry in Birmingham working on the isolation of the troponin components, I felt a bit lost in the Continental muscle field. At that time Britain was for decades a stronghold in muscle research (see Gerald Elliott's contribution in this issue), and Sam Perry took me occasionally along to the rather loose organisation known as the Muscle Dining Club. It was immediately clear that something analogous on the Continent would not work with scientists coming from the Northern, Southern, and Eastern European countries (and perhaps even from Britain) just for an informal Muscle Evening Dinner. So after contacting a few friends including Caspar Rüegg

M. C. Schaub $(\bowtie)$

Institute of Pharmacology and Toxicology, University of Zurich, Winterthurerstrasse 190, CH-8057 Zurich, Switzerland

e-mail: schaub@pharma.uzh.ch
(Heidelberg), Jean Léger (Paris), and late Gabriel Hamoir (Liège) we founded the European Muscle Club aiming at bringing muscle researchers together on the European Continent, exchanging ideas, and holding annual meetings every year in another European country. The Club should be open not only for the established researchers but also for young and new people in the field.

The first meeting was organised by late Gabriel Hamoir in Liège (Belgium) with 47 attendees. As summarised in Table 1, the attendance gradually increased over the years, fluctuating between 200 and 300 (which is an ideal size for specialised scientific meetings) since the 1980s. A memorable discussion took place at the very first meeting in Liège which I won't keep hidden. In search for a name "Continental Muscle Club" was favoured over "European Muscle Club". To be frank, first, we were not sure whether the British would think it worth to cross the Channel for joining us in future meetings, and second, some Continentals were afraid to become overpowered and dominated by the British stronghold in muscle research. Fortunately, the unifying term "European" won out and more and more British muscle researchers used to participate in the EMC meetings. It may be said without scruples that the EMC was instrumental in bringing muscle researchers from different laboratories and different European countries together and was thus helping to induce cooperations. Over the years the scientific quality of the meetings has significantly improved. One wonders whether the improved scientific standard began to attract the British muscle scientists to join the meetings, or whether the British contributions raised the scientific standard on the Continent. It does look, however, as if both sides would have contributed their share. In any case, Table 1 tells us that past EMC meetings have already four times taken place in Britain. 
Table 1 Past European muscle conferences with organisers and approximate numbers of participants in the last column

\begin{tabular}{|c|c|c|c|c|}
\hline 1972 & Liège & Belgium & Gabriel Hamoir & 47 \\
\hline 1973 & Lenzburg & Switzerland & Marcus Schaub & 68 \\
\hline 1974 & Budapest & Hungary & Endre Biro & 80 \\
\hline 1975 & Aarhus & Denmark & Jack Lowy & 120 \\
\hline 1976 & Bressanone & Italy & Alfredo Margreth & 160 \\
\hline 1977 & Saclay/Paris & France & Ingrid Pinset-Härström & 110 \\
\hline 1978 & Warszawa & Poland & Witek Drabikowski & 120 \\
\hline 1979 & Heidelberg & Germany & Caspar Rüegg & 220 \\
\hline 1980 & Salzburg & Austria & Vic Small & 235 \\
\hline 1981 & Galway & Ireland & D. R. Headon & 110 \\
\hline 1982 & Leicester & UK & Arthur Rowe/Clive Bagshaw & 210 \\
\hline 1983 & Szeged & Hungary & Ferenc Guba/Ödön Takacs & 180 \\
\hline 1984 & Gwatt & Switzerlnad & Marcus Schaub & 240 \\
\hline 1985 & Ulm & Germany & Reinhardt Rüdel & 230 \\
\hline 1986 & Montpellier & France & Ridha Kassab & 225 \\
\hline 1987 & Tiberias & Israel & Avraham Oplatka/Benny Geiger & 180 \\
\hline 1988 & Abano Terme & Italy & Ugo Carraro & 210 \\
\hline 1989 & Lunteren & Netherlands & Tugendhold Blangé & 220 \\
\hline 1990 & Brussels & Belgium & Georges Maréchal & 260 \\
\hline 1991 & Oxford & UK & Chris Ashley/Gerald Elliott & 230 \\
\hline 1992 & Bielefeld & Germany & Harald Jockusch/Horst Hinssen & 270 \\
\hline 1993 & Gwatt & Switzerland & Marcus Schaub & 235 \\
\hline 1994 & Bochum & Germany & Ludwig Heilmeyer & 220 \\
\hline 1995 & Firenze & Italy & Colomo/Cecchi/Poggesi & 300 \\
\hline 1996 & Montpellier & France & Tom Barman/Franc Travers & 240 \\
\hline 1997 & Hannover & Germany & Bernhard Brenner & 190 \\
\hline 1998 & Lund & Sweden & Anders Arner/Per Hellstrand & 226 \\
\hline 1999 & York & UK & John Sparrow/Justin Molloy & 216 \\
\hline 2000 & Berlin & Germany & Ingo Morano & 195 \\
\hline 2001 & Pavia & Italy & Roberto Bottinelli/Carlo Reggiani & 250 \\
\hline 2002 & Lunteren & Netherlands & Ger Stienen & 180 \\
\hline 2003 & Montpellier & France & Patrick Chaussepied/Michel Pucéat & 340 \\
\hline 2004 & Isola d'Elba & Italy & Vincenzo Lombardi & 270 \\
\hline 2005 & Debrecen & Hungary & Istvan Jona & 170 \\
\hline 2006 & Heidelberg & Germany & Rainer Fink & 220 \\
\hline 2007 & Stockholm & Sweden & Anders Arner/Lars Larsson & 240 \\
\hline 2008 & Oxford & UK & Steven Marston/Charles Redwood & 230 \\
\hline
\end{tabular}

I was leading the EMC with the help of a Committee of 6 to 8 members from 1971 up to 1995 when Ger Stienen from Amsterdam took over, and almost 10 years later Anders Arner from Stockholm started the present period. We repeatedly asked the members whether we should more formalise the society, but the vast majority wanted to keep it as informal as it was. Nevertheless, a number of things have changed since its beginnings. The further development of the EMC may be visualised by a shortcut of the logo in Fig. 1: white/black/white mutates into colourful red/blue/yellow and reverts back to Oxford blue/white/blue contrasting with the original black and white pattern. I designed this logo in the late 1970s which was used for all meetings ever since. In 2002 with the meeting in Lunteren (The Netherlands) Ger Stienen rejuvenated it by adding the colours, and on the Oxford-2008 abstract book it again

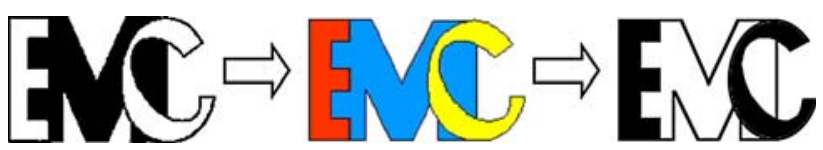

Fig. 1 Changing appearance of the EMC logo originally standing for "European Muscle Club" and since the "Club" has mutated to "European Society for Muscle Research", it stands for "European Muscle Conference" 
shines in decent blue and white. In the near future the now chairman Anders Arner together with the committee will probably propose statutes to formalise the Society as a nonprofit organisation in order to better regulate and secure the financial side. At present the Society membership is free, but between 10 and 20 EURO from each personal meeting registration costs are transferred to the chairman's account to aliment secretarial expenses. Some of this money also allows for travel support of young scientists to come to the meetings. At the time when the Iron Curtain was still in operation, the EMC invited and supported the attendance of muscle scientists from Eastern European countries (including Ukraine and former Soviet Union).

How come the "Club" has changed its name to "European Society for Muscle Research"? With the advent of the "Journal of Muscle Research and Cell Motility" (JMRCM) starting in 1980 (see Richard Tregear's contribution in this issue) in which the yearly meeting abstracts were now officially published, the Club gained some wider international visibility and started to attract participants from all over the world. By that time, the term "Club" became a little disreputed; I was repeatedly asked by the bank with the EMC account what kind of body building club am I managing. Actually, at the EMC 1985 in Ulm (Germany) the organiser Reinhardt Rüdel invited a group of professional body builders (men and women) who presented a breathtaking performance in applied myology. However, times changed and it got more and more difficult to raise financial support from National Science Foundations and other grant-giving organisations for the "Club Meetings". Finally, 1988 at the meeting of Ugo Carraro (Padova) in Abano Terme the name "European Society for Muscle Research" (ESMR) was adopted. The term EMC (short for European Muscle Conference) was kept with its logo as label for the yearly meetings.

Another pleasing aspect of the EMC-ESMR arises from its fertility: there are three children. The first descendant was 1976 the "Club Francophone du Muscle" mainly comprising the French speaking muscle scientists in France, Belgium, and Switzerland. The purpose was to hold yearly meetings, in addition to the EMC, consequently using only French (English was forbidden) in order to feel at ease in talking and discussing together. I believe this custom was after a few years silently dying out. The second descendant was the "European Cytoskeletal Club". The meeting program got overloaded by the cytoskeletal field which started growing rapidly in the 1970s. In order to avoid parallel sessions at the meetings the Cytoskeletal Club started its own meeting schedule in 1981 in Nyon (Switzerland) organised by Giulio Gabbiani (Geneva). The original idea was to occasionally hold common meetings of both Clubs together. One such common meeting was organised by Avraham Oplatka and Benny Geiger 1987 in
Tiberias (Israel), and by Marcus Schaub 1993 in Gwatt (Switzerland). Facing similar problems as our EMC, the "European Cytoskeletal Club" mutated 1990 to the more respectable "European Cytoskeletal Forum" known since then by its acronym ECF.

The third descendant is the "Alternative Muscle Club" (AMC) founded in 1981 by scientists regularly attending the EMC meetings. The AMC was holding its twentyseventh meeting at Leeds in July 2008. The AMC meetings offer a forum for (open quotes) "PhD students and Postdocs working on muscle, cellular motility, molecular motors or associated disease states" (close quotes). To me this confession sounds rather familiar, it could as well be derived from the EMC-ESMR guidelines, and that is what makes them both so agreeable and congenial. When one gets the announcements from the AMC, hesitation for onesecond, then ah yes, that's in Britain, which does not even appear in its name, of course, the independent British stronghold of muscle research is shining through.

This brings me to a last short consideration. In Europe, at least on the Continent, muscle research is eking out a somewhat meagre existence in terms of recognition and grant support. Grant applications for research on physiology, biochemistry, biophysics, cell biology, even on genetics and genomics, often meet with relegation to lower priorities if concerning (only) muscle. That is distressful in view of the massive support being granted, for instance, to research in neurobiology. Muscle is so rich and diverse in topics it offers for research. Fundamental biological paradigms have been recognised by working on muscle like metabolic pathways, tissue plasticity, genetics and disease, calcium signalling, electrophysiology, structure-function relations, etc.; moreover, muscle presents the most promising source for interdisciplinary approaches. This requires intensive cooperation between muscle researchers, and this unfortunately is not always well accepted. As opposed to neurobiology, diabetes, or cardiology, where researchers form coherent scientific communities powerful in pursuing their interests, muscle scientists appear more loosely organised and are disseminated in small groups often affiliated to institutions one would not expect them. Can that be improved? The EMC-ESMR together with the journal JMRCM might provide a combined platform that could and should be better exploited for muscle research in Europe. Presumably we muscle people all like the JMRCM, but seldom publish in it. Its impact factor was reeling over the past 5 years from 1.3 up to 1.7 , then falling back to 0.9 and now regaining 1.7. It should climb up to over 4 to have a reasonable impact on the scientific community, let's try to aim at that mark.

With that I like to finish by thanking the ESMR committee, chairmen and all the past meeting organisers (who really did the lion's share of the work) for their 
commitment and efforts over three decades as well as the editors of the JMRCM. A lot has been achieved, but we should not sit back, because a still greater challenge lies ahead. We are particularly grateful to the young muscle scientists each year joining the EMC, thanks to them the Society is thriving. They muster our hope for the future of muscle research in Europe and beyond. 